\title{
Arbeidsmarktrelevantie van grote MBO-opleidingen
}

Citation for published version (APA):

Huijgen, T. G., \& Meng, C. M. (2013). Arbeidsmarktrelevantie van grote MBO-opleidingen. ROA. ROA Fact Sheets No. 001 https://doi.org/10.26481/umarof.2013001

Document status and date:

Published: 01/01/2013

DOI:

10.26481/umarof.2013001

Document Version:

Publisher's PDF, also known as Version of record

\section{Please check the document version of this publication:}

- A submitted manuscript is the version of the article upon submission and before peer-review. There can be important differences between the submitted version and the official published version of record.

People interested in the research are advised to contact the author for the final version of the publication, or visit the DOI to the publisher's website.

- The final author version and the galley proof are versions of the publication after peer review.

- The final published version features the final layout of the paper including the volume, issue and page numbers.

Link to publication

\footnotetext{
General rights rights.

- You may freely distribute the URL identifying the publication in the public portal. please follow below link for the End User Agreement:

www.umlib.nl/taverne-license

Take down policy

If you believe that this document breaches copyright please contact us at:

repository@maastrichtuniversity.nl

providing details and we will investigate your claim.
}

Copyright and moral rights for the publications made accessible in the public portal are retained by the authors and/or other copyright owners and it is a condition of accessing publications that users recognise and abide by the legal requirements associated with these

- Users may download and print one copy of any publication from the public portal for the purpose of private study or research.

- You may not further distribute the material or use it for any profit-making activity or commercial gain

If the publication is distributed under the terms of Article $25 \mathrm{fa}$ of the Dutch Copyright Act, indicated by the "Taverne" license above, 


\section{Arbeidsmarktrelevantie van grote MBO-opleidingen}

\section{ROA Fact Sheet}

ROA-F-2013/1

Researchcentrum voor Onderwijs en Arbeidsmarkt | ROA Research Centre For Education and the Labour Market / ROA 


\section{Inleiding}

Het middelbaar beroepsonderwijs (mbo) biedt een grote verscheidenheid aan soorten opleidingen. Behalve dat er twee leerwegen zijn, de beroepsbegeleidende leerweg (bbl) en de beroepsopleidende leerweg (bol) en vier niveaus verschillen de opleidingen ook van karakter. Zo zijn sommige opleidingen vooral bedoeld als voorbereiding op een vervolgtraject in het onderwijs en andere eveneens als voorbereiding op de arbeidsmarkt. Dit factsheet richt zich met name op dit laatste aspect. Op basis van de schoolverlatersdata van de BVE-monitoren 2007 tot en met $201 \mathrm{II}$ voor een I8o-tal grotere crebo opleidingen ${ }^{\mathrm{I}}$ gekeken hoe de gediplomeerden die zich aanbieden op de arbeidsmarkt terecht zijn gekomen. De cijfers laten zien dat er tussen deze opleidingen nogal wat verschillen zijn als het gaat om succes op de arbeidsmarkt maar ook dat een indicator als het werkloosheidspercentage alleen niet voldoende is om het arbeidsmarktsucces van een opleiding te bepalen.

\section{Succes op de arbeidsmarkt}

Een belangrijke vraag die beantwoord moet worden als het gaat om het arbeidsmarktsucces van een opleiding is de vraag in hoeverre de gediplomeerden er in zijn geslaagd om een baan te vinden. ${ }^{2}$ Wat is met andere woorden het werkloosheidspercentage onder de gediplomeerden. Daarnaast is echter ook de kwaliteit van het gevonden werk van belang. In hoeverre de schoolverlaters er in slagen om werk te vinden dat aansluit wat niveau betreft op hun gevolgde opleiding zegt iets over hun kwalificaties en dus over hun gevolgde studie. Ook de aansluiting naar richting is in dit kader van belang. Leerlingen kiezen, ook in het mbo, voor een bepaalde opleidingsrichting omdat deze richting hun interesse heeft en/of omdat ze verwachten dat ze met deze opleidingsrichting later een goede baan zullen kunnen krijgen. Het overgrote deel van de gediplomeerden zal dan ook op zoek gaan naar werk, en het meest tevreden zijn met werk dat wat richting betreft aansluit bij hun behaalde diploma. Behalve dat er gekeken is naar het werkloosheidspercentage wordt er in dit factsheet dus ook gekeken in hoeverre de gediplomeerde uitstroom van de crebo opleidingen in passend werk terecht gekomen is als het gaat om de vereiste richting en het vereist opleidingsniveau van het werk. Naast het al dan niet vinden van (passend) werk geeft de snelheid waarmee dit werk gevonden wordt ook een indicatie van het arbeidsmarktsucces. In de bijlage staan de genoemde indicatoren per crebo opleiding weergegeven.

In de tabel in de bijlage staat eveneens het percentage van de gediplomeerden dat aangeeft aan een vervolgoplei- ding begonnen te zijn. Er is zeker geen sprake van een één op één relatie tussen deze indicator en het karakter van een opleiding als het gaat om de opleiding als voorbereiding op het vervolgonderwijs dan wel de arbeidsmarkt. Voor veel opleidingen geldt dat ze voor beide 'markten' opleiden. Een opleiding met een hoge doorstroom naar het vervolgonderwijs zal echter in de regel een lagere directe arbeidsmarktrelevantie hebben dan een opleiding met een lage doorstroom naar het vervolgonderwijs. Alhoewel het vervolgonderwijs en dus het succes van een opleiding als voorbereiding hierop buiten het kader van dit factsheet vallen geeft deze indicator wel een idee over de mate waarin een opleiding bedoeld is als voorbereiding op een intrede op de arbeidsmarkt en dus iets meer duiding aan de indicatoren in de andere kolommen.

Van de geselecteerde opleidingen is $5 \%$ van de gediplomeerden werkloos anderhalf jaar na afstuderen. Er zijn echter grote verschillen tussen de verscheidene opleidingen. Een aanzienlijk aantal opleidingen kent weinig tot geen werklozen maar er zijn ook opleidingen waar het aandeel werklozen boven de $20 \%$ ligt. Gelukkig komt het merendeel van de werkenden terecht in een passende baan. Zes van de tien werkenden heeft een baan die zowel wat niveau als wat richting betreft aansluit bij de gevolgde opleiding. Een kwart heeft werk onder het eigen opleidingsniveau, ongeveer even zo vaak in het eigen als buiten het eigen domein.

Van degenen die zich aanbieden op de arbeidsmarkt vindt $90 \%$ vrijwel direct een baan. De gemiddelde intredewerkloosheid is dan ook laag. Er zijn echter ook wat deze indicator betreft weer grote verschillen tussen de crebo opleidingen. Er zijn opleidingen waarvan de afgestudeerden duidelijk moeite hebben met het vinden van werk en waar $30 \%$ tot $40 \%$ langer dan een maand aan het zoeken is terwijl de afgestudeerden van andere opleidingen vrijwel allemaal direct aan het werk zijn kunnen gaan.

Dat het mbo zowel voor de arbeidsmarkt opleidt als voor het vervolgonderwijs blijkt uit de laatste kolom in de tabel in de bijlage. Voor sommige opleidingen geldt dat meer dan $70 \%$ van de gediplomeerden aan een vervolgopleiding begint terwijl bij andere opleidingen slechts een enkeling begint aan een vervolgstudie. In veel gevallen zal een opleiding zich echter moeten richten op zowel de arbeidsmarkt als de mogelijke vervolgstudies omdat de doorstroom naar beiden aanzienlijk is. In totaal begint zo'n $40 \%$ van de in dit factsheet besproken gediplomeerden aan een vervolgopleiding.
I. Voor dit factsheet is een 'grote' crebo opleiding gedefinieerd als een opleiding waarvan minstens 20 respondenten zich aan hebben geboden op de arbeidsmarkt over de periode 2007-20II. In totaal ging het om iets meer dan $\mathrm{I} 6.800$ respondenten.

2. De lezer dient ermee rekening te houden dat een $\mathrm{MBO}$ niveau I diploma geen formele startkwalificatie is. 


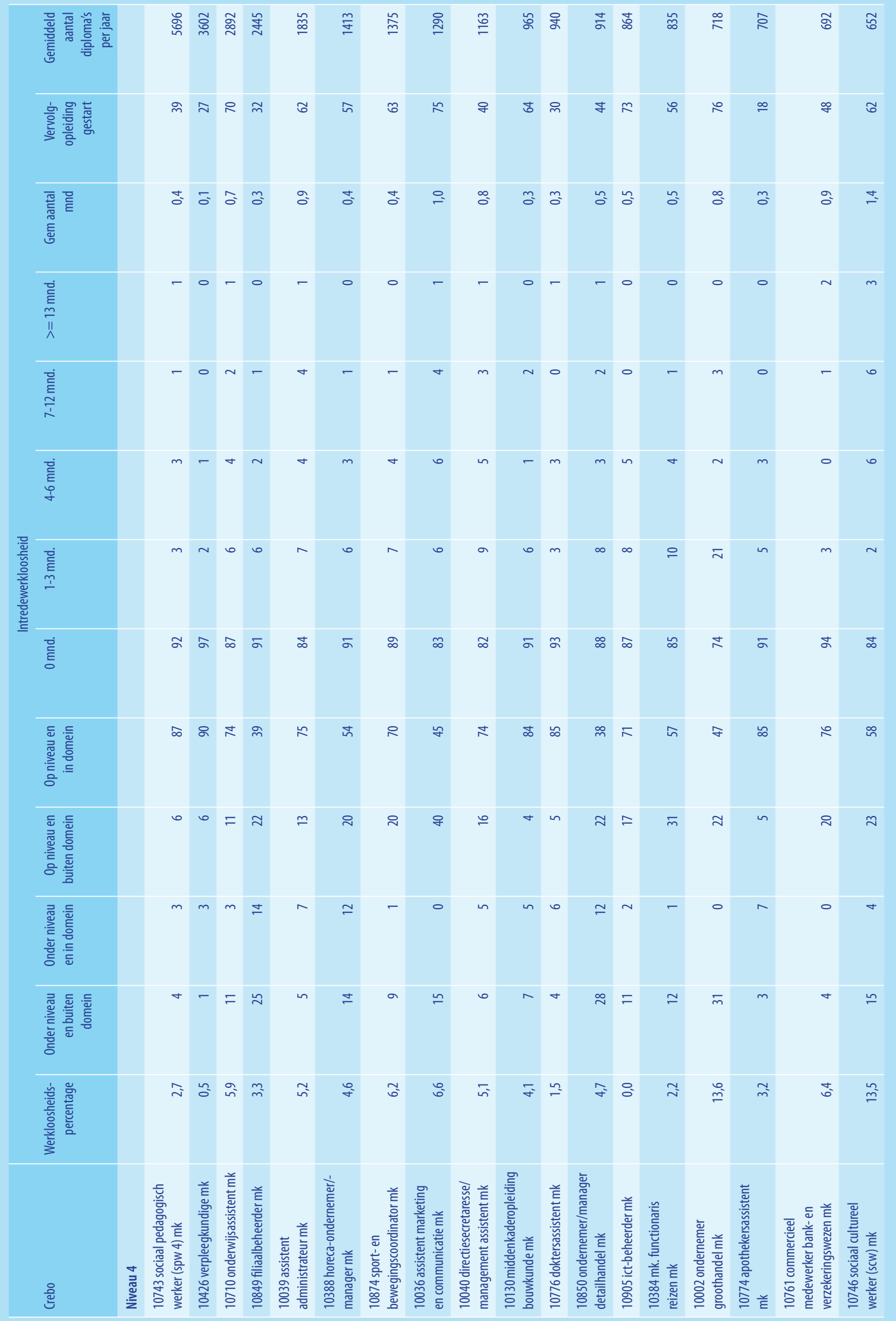




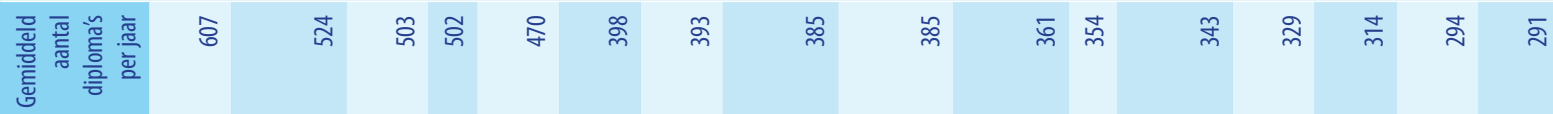

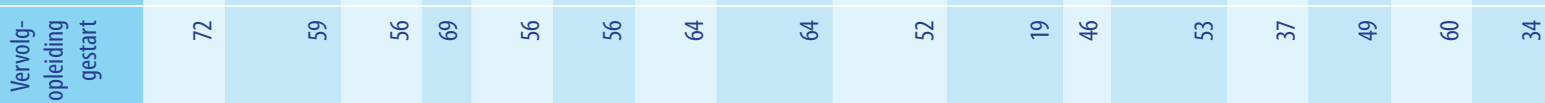

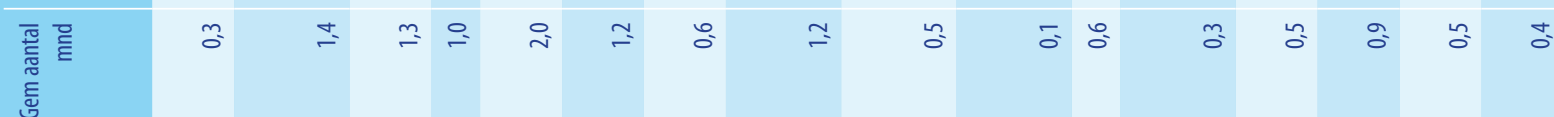

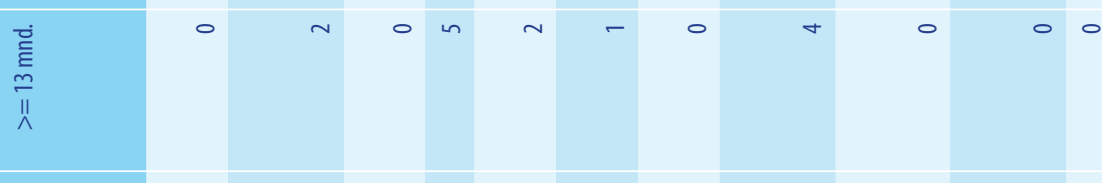

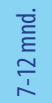

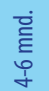

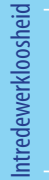

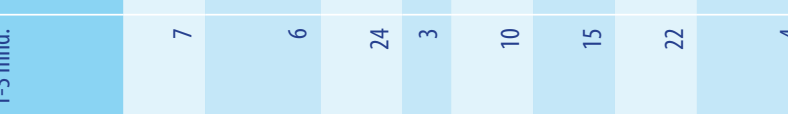

离

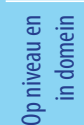

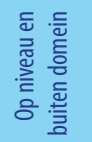

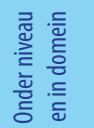

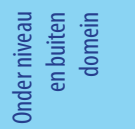

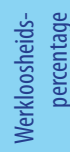

万๐

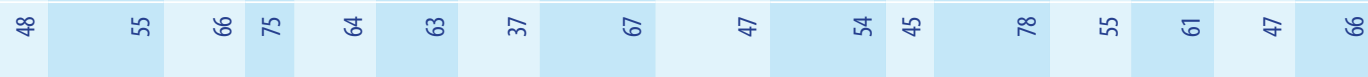

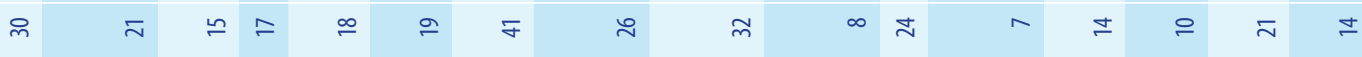

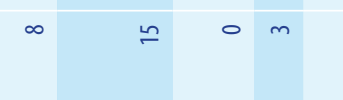

$\pm$

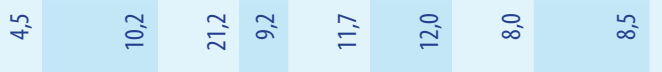

$\therefore \quad 28$

$\therefore$ ㅎํ $\stackrel{\circ}{=}$

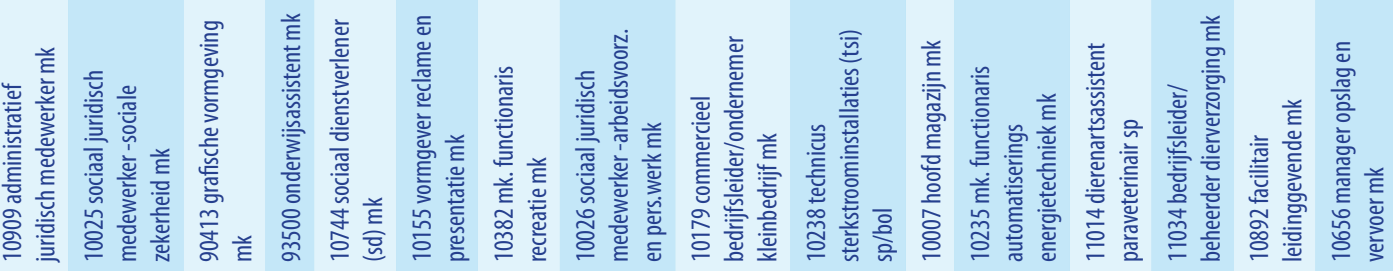




\begin{tabular}{|c|c|c|c|c|c|c|c|c|c|c|c|c|c|c|c|c|c|c|}
\hline 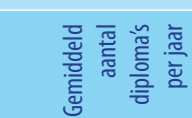 & $\stackrel{\infty}{\sim}$ & $\underset{\sim}{\sim}$ & $\lesssim$ & $\bar{\beth}$ & $\stackrel{\approx}{\approx}$ & $\approx$ & 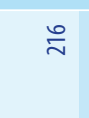 & $\stackrel{m}{\sim}$ & $\stackrel{ }{\sim}$ & $\stackrel{\sim}{~}$ & 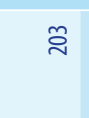 & $\overline{\check{~}}$ & gे & gे & & 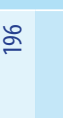 & 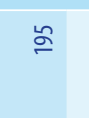 & $\approx$ \\
\hline 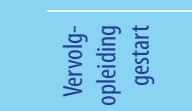 & $\stackrel{\infty}{m}$ & $F ?$ & $\approx$ & $\approx$ & in & $\delta$ & in & $F$ & $\stackrel{\infty}{m}$ & 8 & in & $\bar{R}$ & f & $\approx$ & & f & f & $\stackrel{\infty}{m}$ \\
\hline 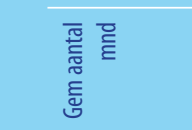 & $\bar{o}$ & $\tilde{o}$ & $\bar{\sigma}$ & $\stackrel{m}{=}$ & $\simeq$ & 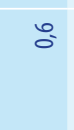 & $\stackrel{2}{=}$ & $\bar{o}$ & $\stackrel{\infty}{\circ}$ & $\therefore$ & $\therefore$ & $\stackrel{-}{\circ}$ & $\therefore$ & ? & & : & $\therefore$ & $\bar{\sigma}$ \\
\hline 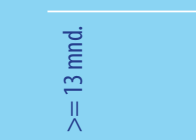 & 0 & 0 & 0 & 0 & 0 & 0 & $r$ & 0 & 0 & 0 & 0 & 0 & 0 & 0 & & 0 & 0 & 0 \\
\hline 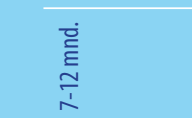 & 0 & $\sim$ & 0 & a & in & 0 & 0 & 0 & $\sigma$ & 0 & 0 & 0 & 0 & $\sim$ & & 0 & 0 & 0 \\
\hline 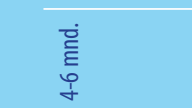 & 0 & 0 & 0 & $n$ & 0 & $\sigma$ & $\sim$ & 0 & $\sim$ & 0 & 0 & $\simeq$ & 0 & 0 & & 0 & 0 & 0 \\
\hline वृ & $m$ & $m$ & in & 인 & $\propto$ & I & 은 & $m$ & $\underline{m}$ & 0 & 0 & 으 & - & $\sigma$ & & 0 & 0 & $\sigma$ \\
\hline 离 & s & « & 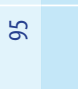 & N & $\approx$ & $\approx$ & $\approx$ & $\sigma$ & $\approx$ & 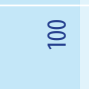 & $\stackrel{8}{0}$ & $\stackrel{\infty}{\curvearrowright}$ & 2 & क & & 음 & $\stackrel{8}{\circ}$ & ஃ \\
\hline 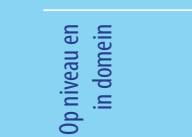 & $\approx$ & 8 & in & I & ถิ & t & in & i̊ & $F$ & $\infty$ & $\widehat{\sigma}$ & $=$ & $\mathscr{f}$ & 8 & & 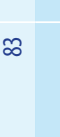 & in & $\stackrel{m}{m}$ \\
\hline 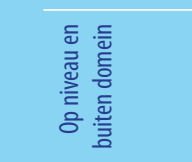 & 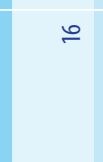 & $=$ & ㅇ & in & $\approx$ & $=$ & $\bar{\sim}$ & a & 요 & $=$ & a & $\sigma$ & \pm & $\infty$ & & $\sim$ & $\sim$ & 0 \\
\hline 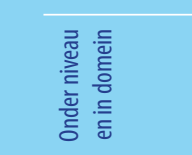 & 0 & $a$ & $\simeq$ & 0 & 0 & 으 & 0 & $=$ & $r$ & $m$ & in & $\infty$ & ㄱ. & 0 & & 으 & m & \& \\
\hline 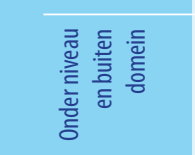 & n & \pm & $\approx$ & - & $a$ & $\cong$ & வ & $\simeq$ & ㄱ. & 0 & a & $\simeq$ & $m$ & $\sim$ & & + & in & ㄱ \\
\hline 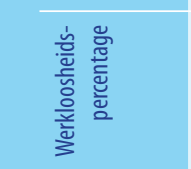 & 8 & $\therefore$ & $\underbrace{\infty}_{0}$ & $\stackrel{8}{\varrho}$ & $\stackrel{\sim}{\simeq}$ & $\stackrel{\circ}{\check{I}}$ & $\widetilde{\infty}$ & : & f & $\stackrel{\cong}{\sim}$ & ถి & $\dot{m}$ & f & $\stackrel{i}{i}$ & & 8 & $\therefore$ & 8 \\
\hline 욜 & 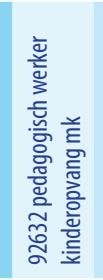 & 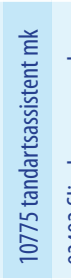 & 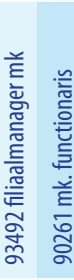 & 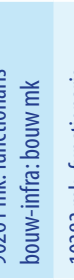 & 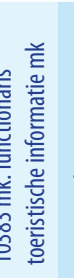 & 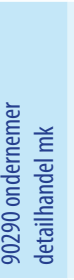 & 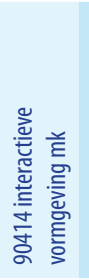 & 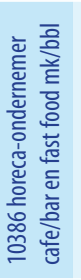 & 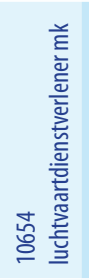 & 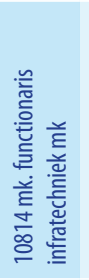 & 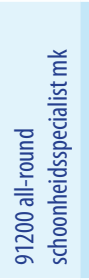 & 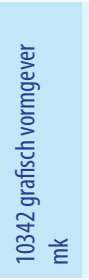 & 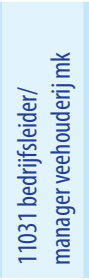 & 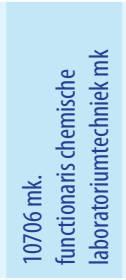 & 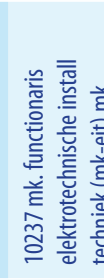 & 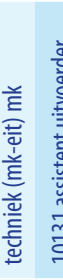 & 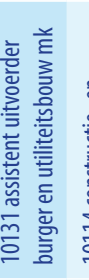 & 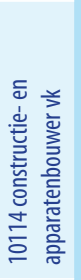 \\
\hline
\end{tabular}




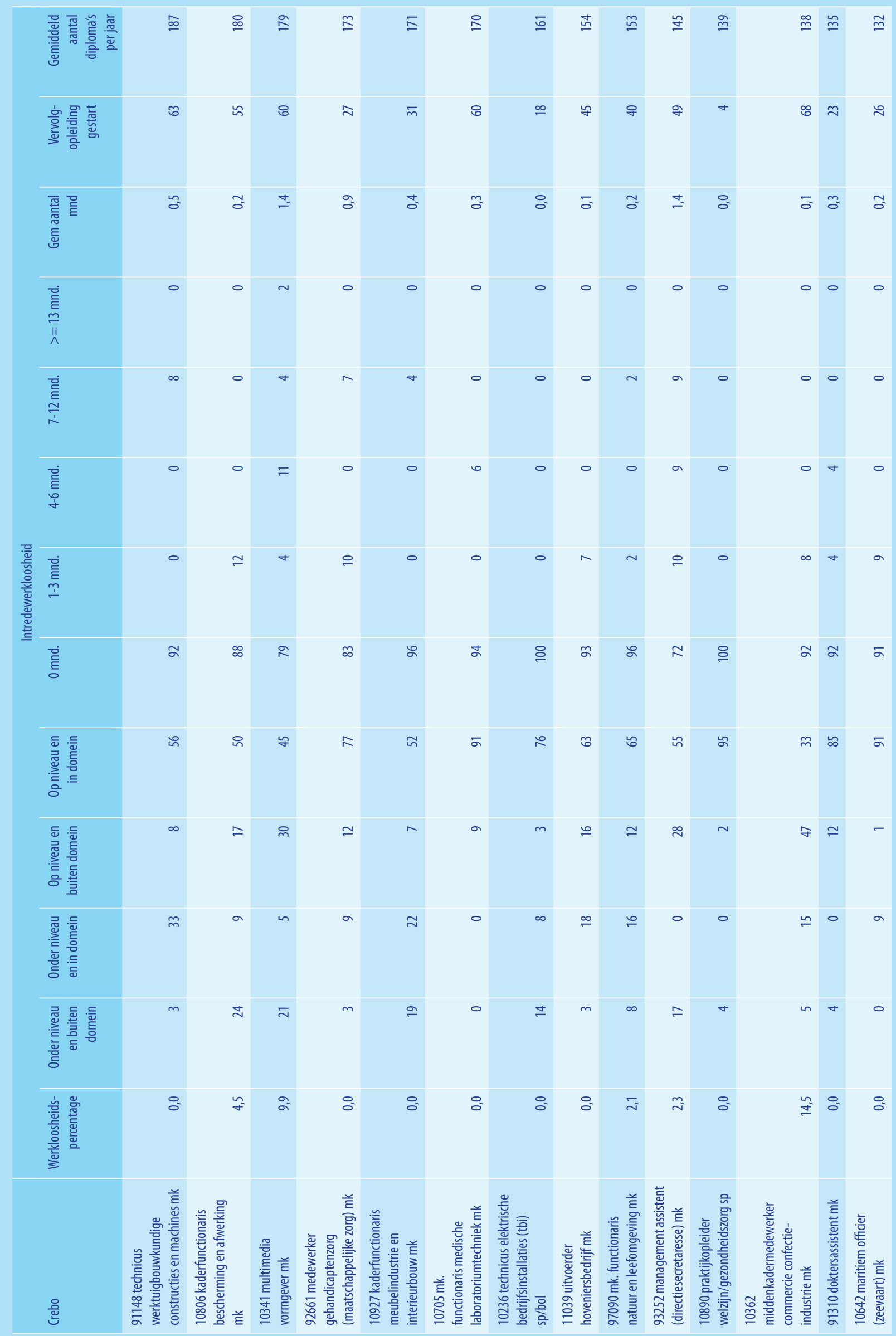




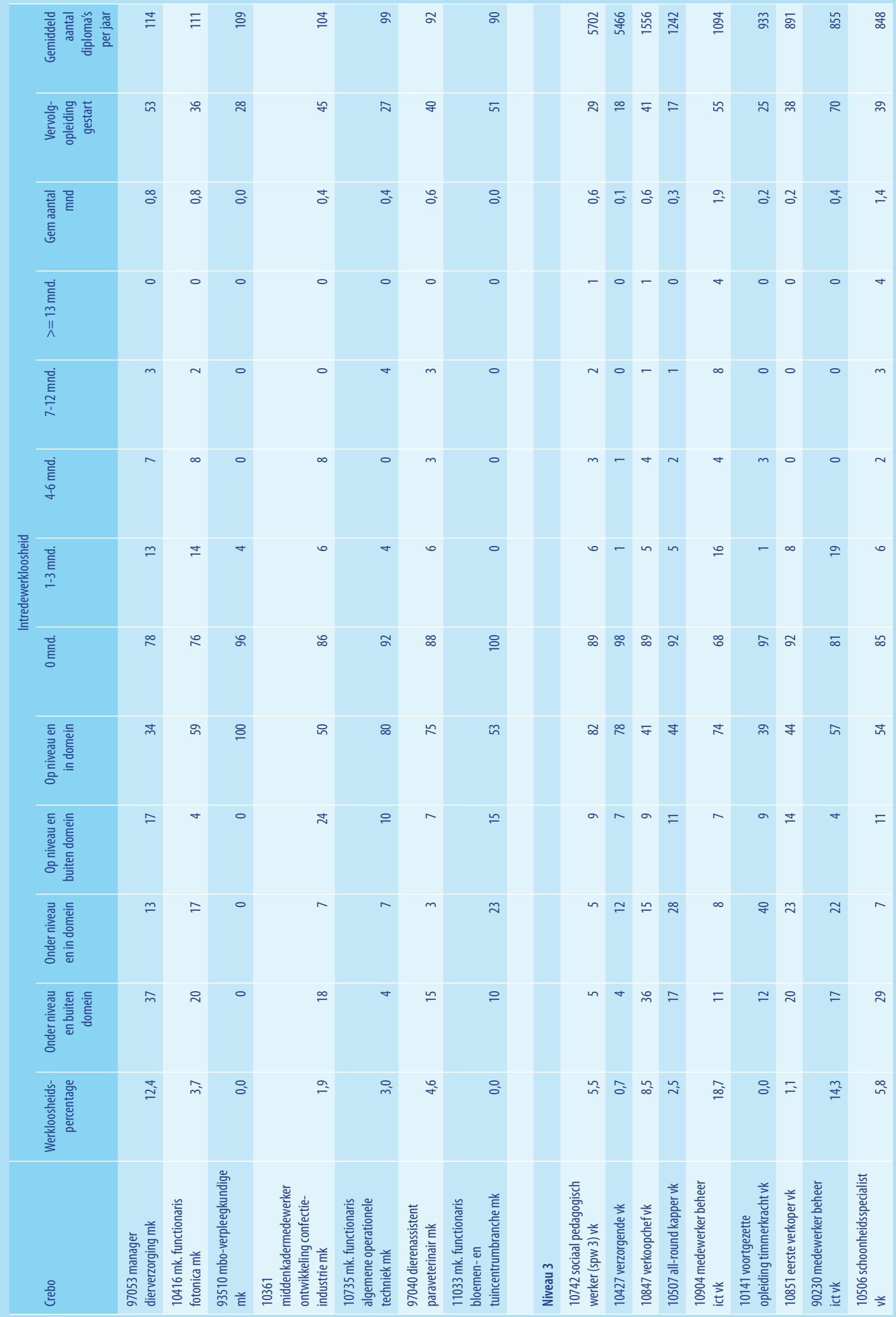




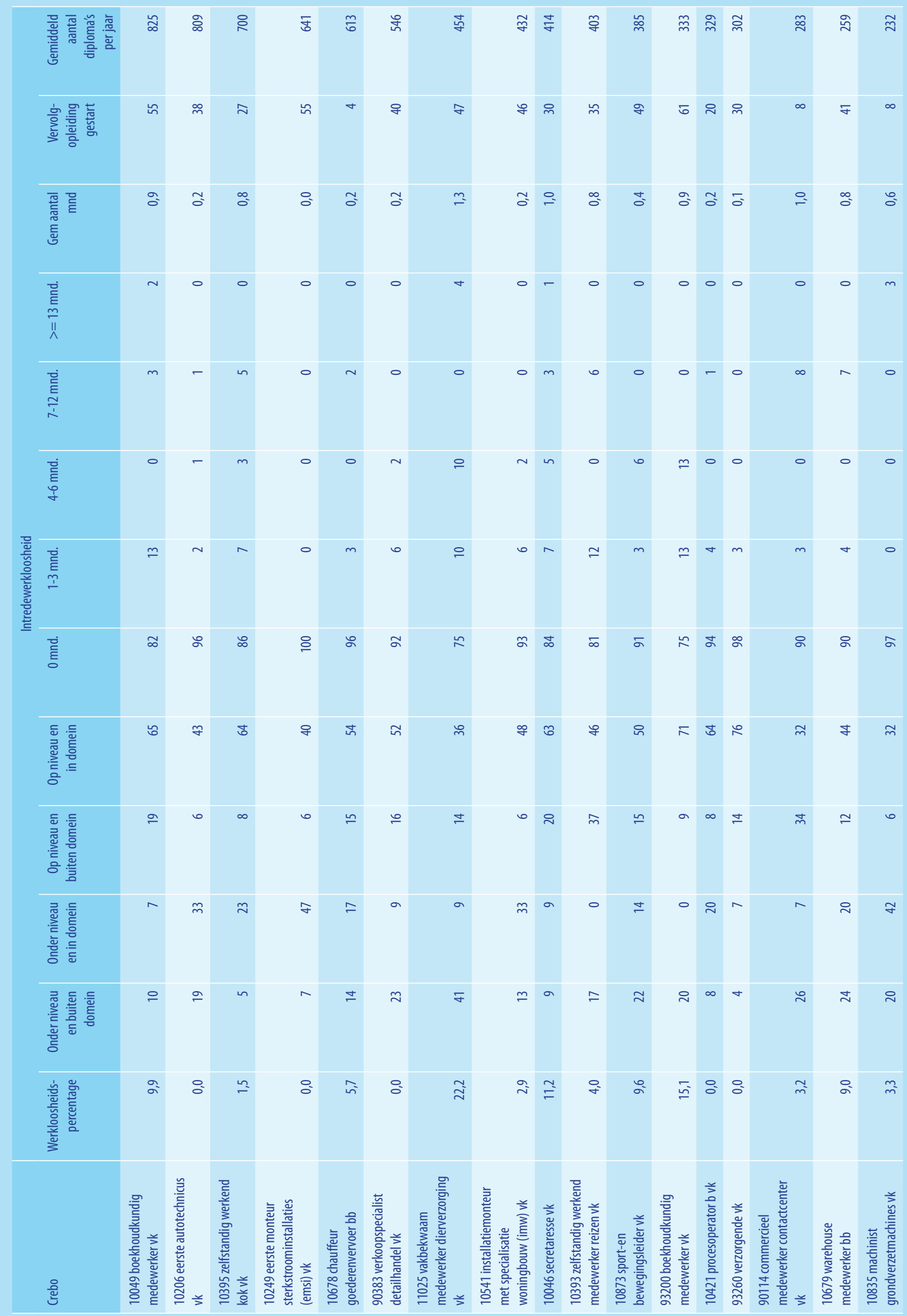




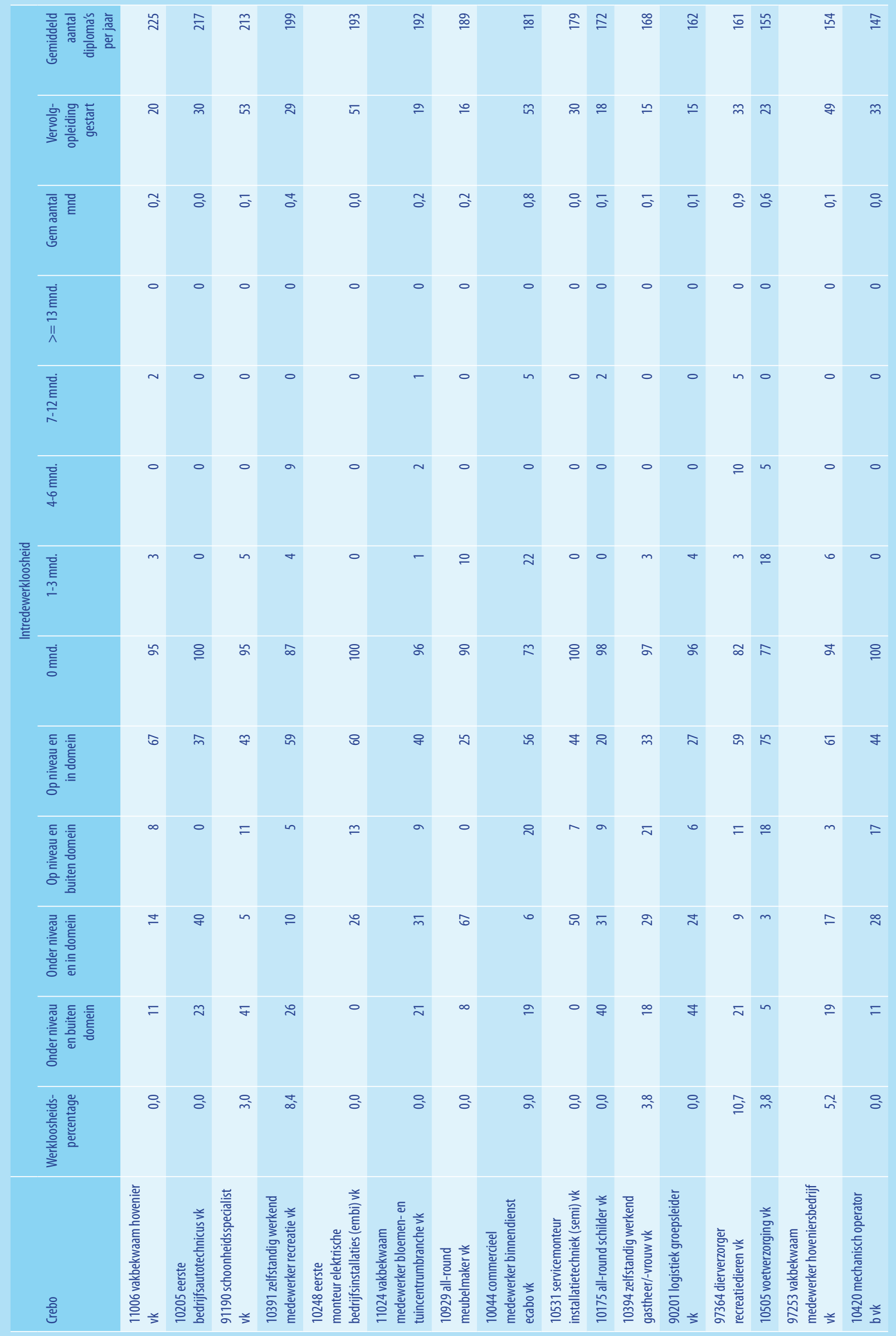




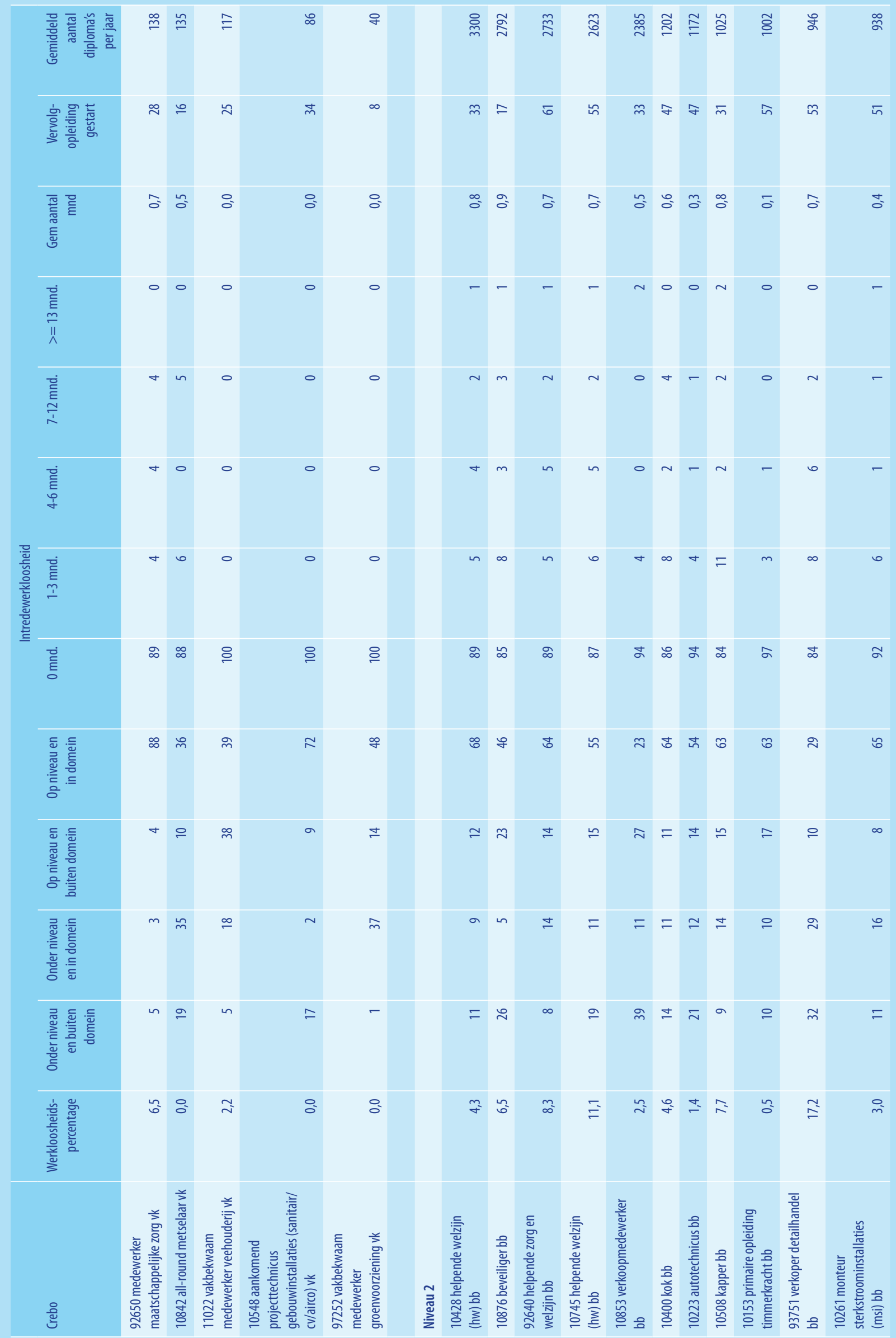




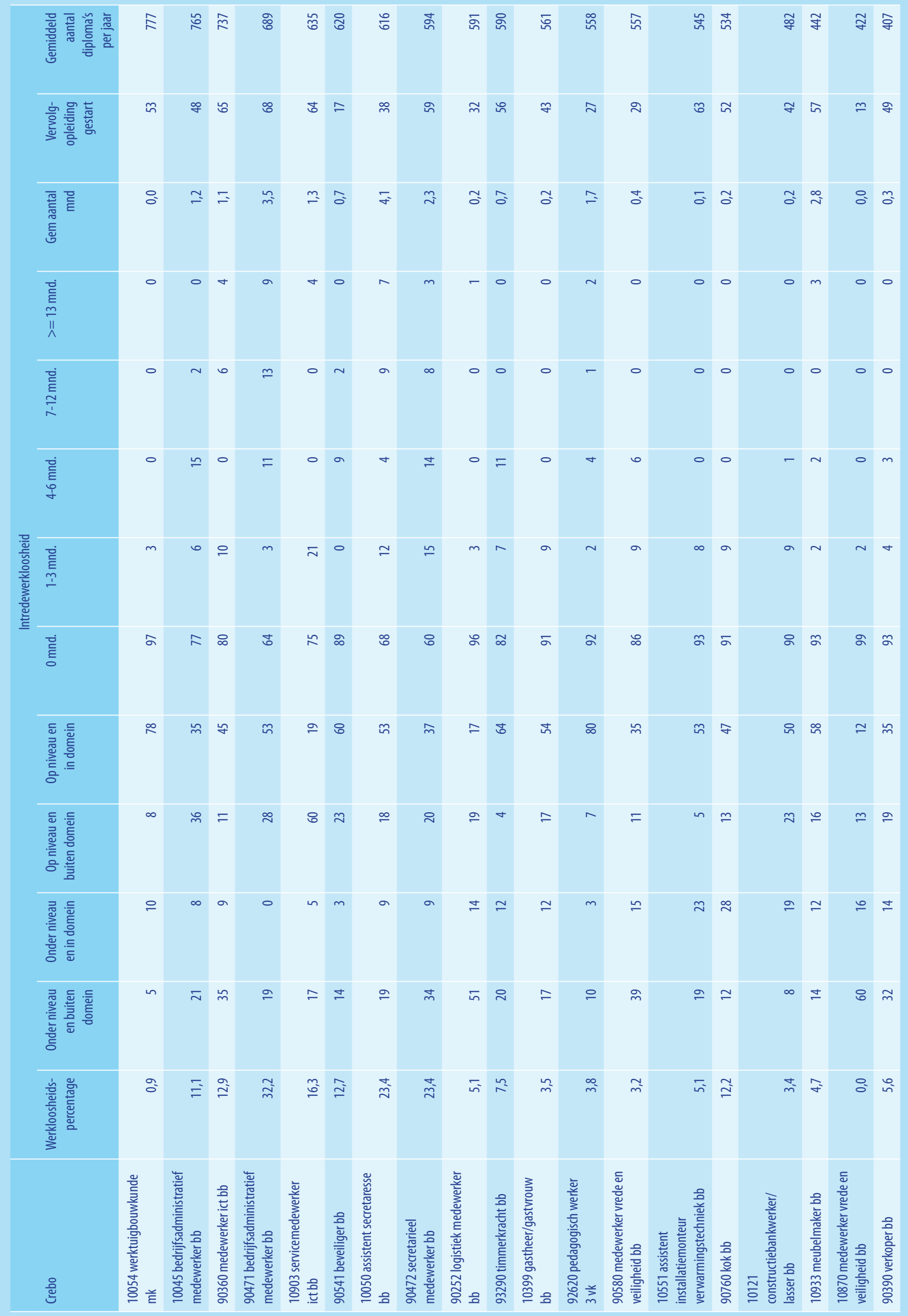




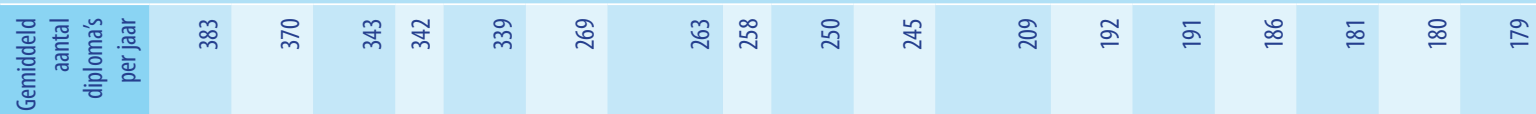

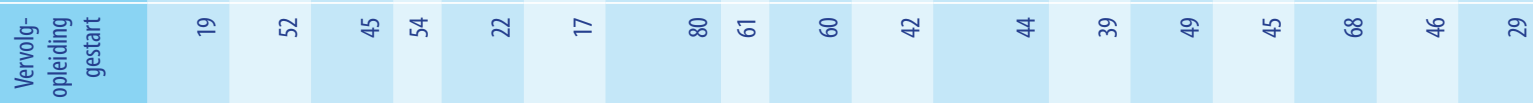

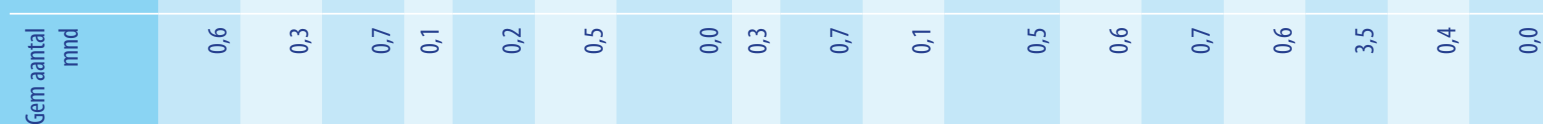

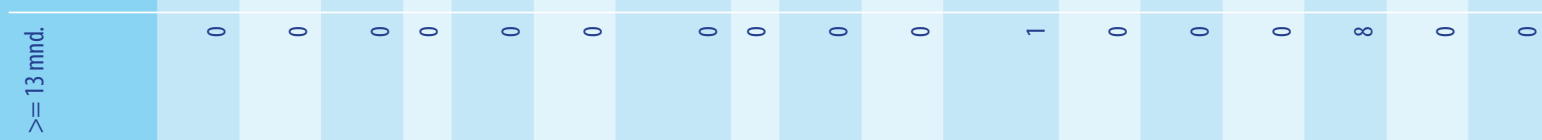

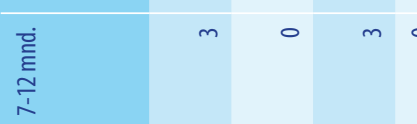

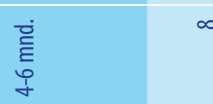

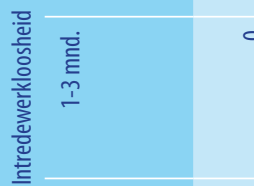

焉

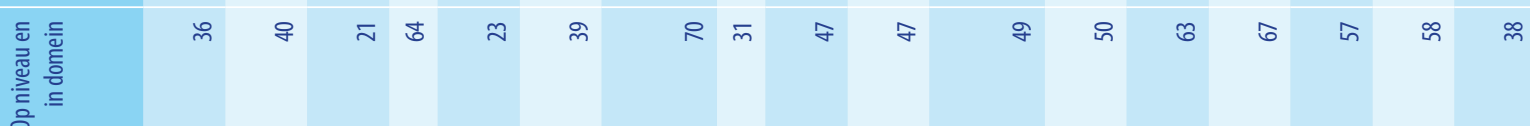

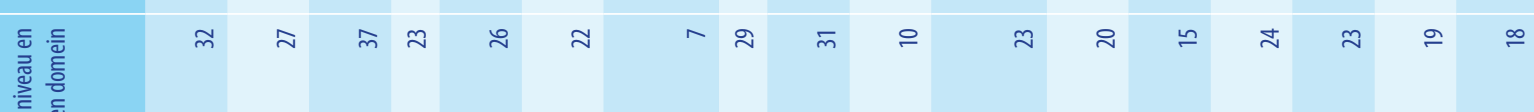
高产

宽

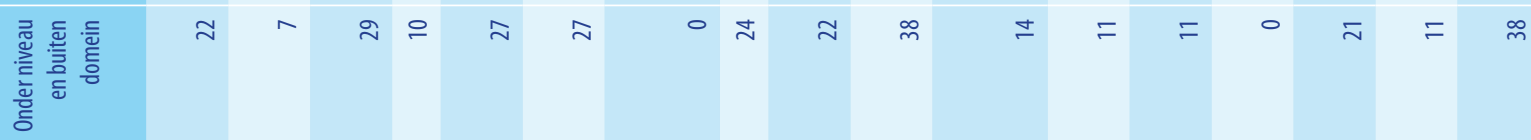

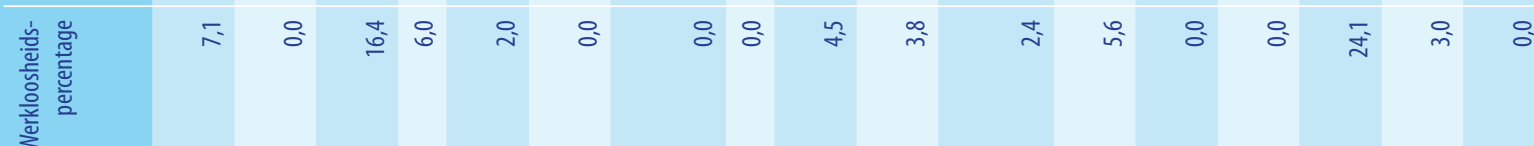
s

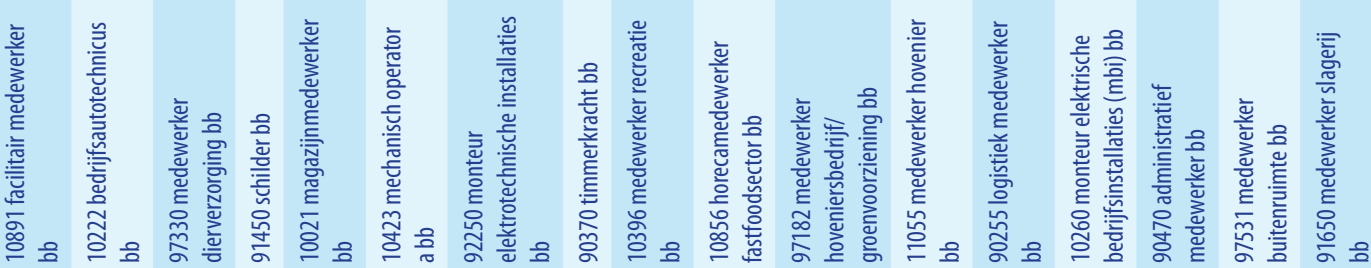




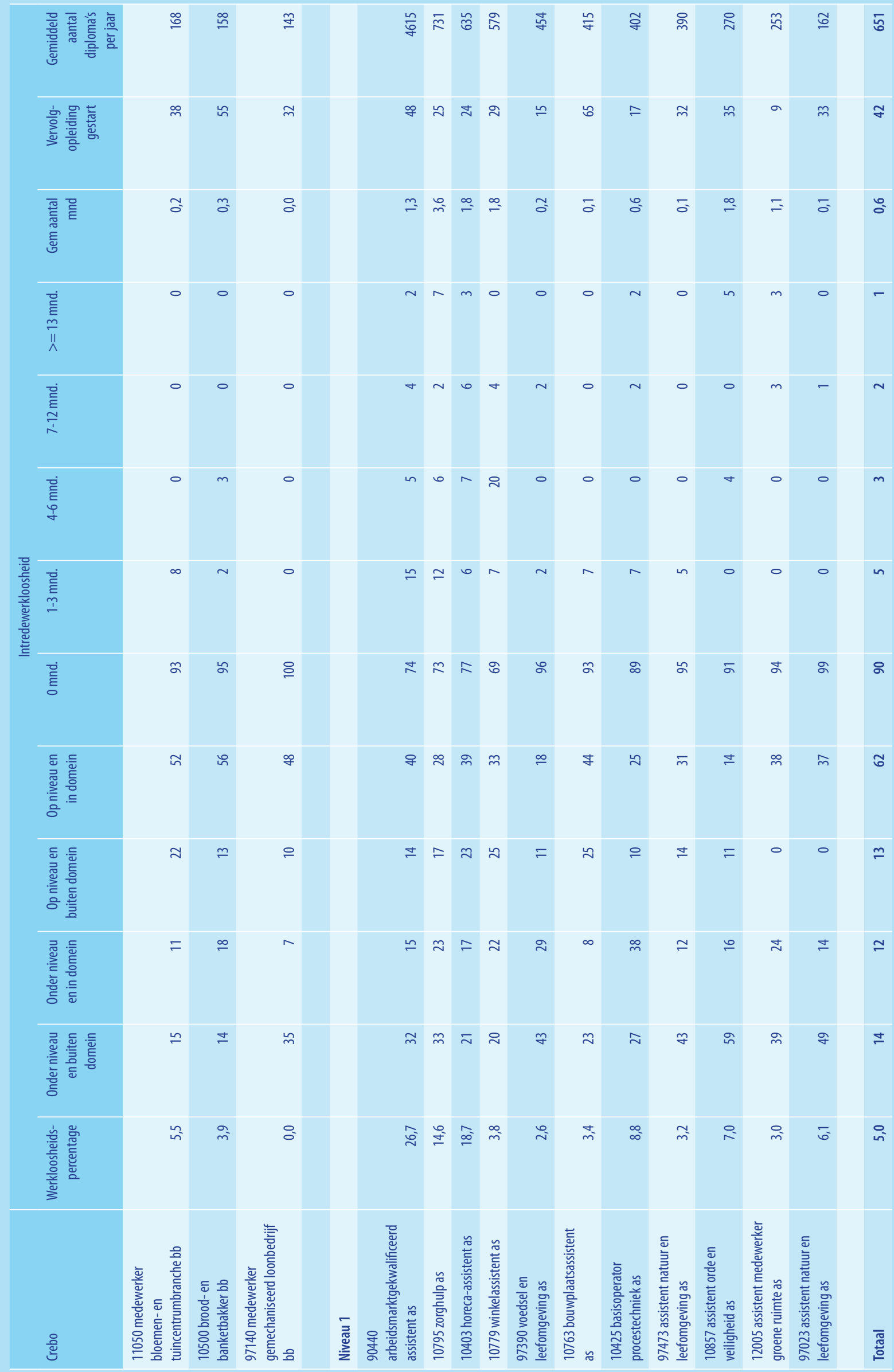


Researchcentrum voor Onderwijs en Arbeidsmarkt

Postbus 616

6200 MD Maastricht

$\mathrm{T}+31433883647$

$\mathrm{F}+31433884914$

secretary-roa-sbe@maastrichtuniversity.n

www.roa.nl

Maastricht University

School of Business and Economics 